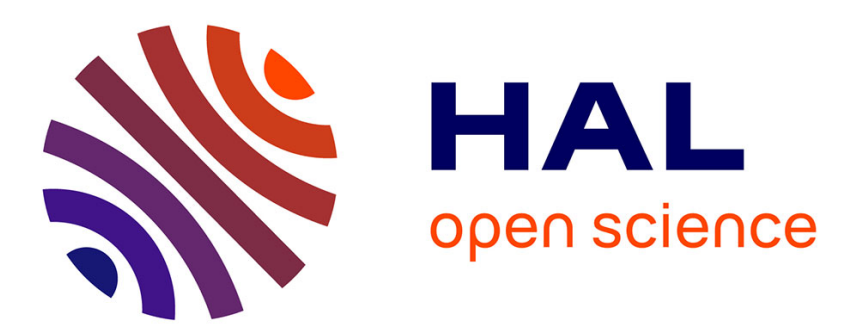

\title{
Sensitivity of effective rainfall amount to land use description using GIS tool. Case of a small mediterranean catchment
}

Sylvain Payraudeau, Marie-George Tournoud, Flavie Cernesson

\section{To cite this version:}

Sylvain Payraudeau, Marie-George Tournoud, Flavie Cernesson. Sensitivity of effective rainfall amount to land use description using GIS tool. Case of a small mediterranean catchment. Physics and Chemistry of the Earth, Parts A/B/C, 2003, 28 (6-7), pp.255 - 262. 10.1016/S1474-7065(03)00035-4 . hal-01575707

\section{HAL Id: hal-01575707 https://hal.science/hal-01575707}

Submitted on 19 Nov 2019

HAL is a multi-disciplinary open access archive for the deposit and dissemination of scientific research documents, whether they are published or not. The documents may come from teaching and research institutions in France or abroad, or from public or private research centers.
L'archive ouverte pluridisciplinaire HAL, est destinée au dépôt et à la diffusion de documents scientifiques de niveau recherche, publiés ou non, émanant des établissements d'enseignement et de recherche français ou étrangers, des laboratoires publics ou privés. 


\title{
Sensitivity of effective rainfall amount to land use description using GIS tool. Case of a small mediterranean catchment
}

\author{
S. Payraudeau a,b M.G. Tournoud ${ }^{\text {b }}$, F. Cernesson ${ }^{\text {a }}$ \\ ${ }^{a}$ Laboratoire Structures et Systemes Spatiaux, CEMAGREF-ENGREF, 500 J.F. Breton 34093 Montpellier, France \\ b Laboratoire Hydrosciences, Universite Montpellier 2-CNRS-IRD (UMR5569), cc056 34095 Montpellier, France
}

Introduction

The hydrological response of the catchment area depends on rain characteristics, on initial moisture conditions and also on landscape characteristics (topography, soil, geology, land cover and hydrography) (Chow et al., 1988). The most basic modelling approach uses lumped models, but they tend to over simplify the catchment heterogeneity (Eagleson, 1972). Therefore, hydrologic models must take into account the spatial variability of land-atmosphere interactions (Beven and Kirkby, 1979), including the spatial variability of land use characteristics through catchment area subdivisions.

For computing convenience, grid structures are adopted in many hydrological models like the SHE model (Abbott et al., 1986) or HYDROTEL (Fortin et al., 1990). These models are very flexible, but may have operational limits stemming from computational constraints, the cumbersome nature of input and output data and the lack of available large-scale data sets for model calibration and validation (Maidment, 1993). Physically-based distributed models, using this structure, are assumed to be based on physical processes that can be represented in a deterministic way (Klemes, 1983). This assumption is possible in laboratories but is not valid on a large scale (Beven, 1989).

The zone-based approach is another solution for catchment subdivisions. Here the catchment is divided into sub-units. Catchment variability can be assessed using two different approaches.

In the first case, the catchment area is divided into homogeneous units based on hydrological response and/ or using topographic geographic characteristics (Ross et al., 1979). Some conclusions can be drawn after the exploration of this concept. The hydrological response units (HRU) are defined intuitively without a careful consideration of the controlling hydrological processes (Kite and Kouwen, 1992). The HRU size is arbitrary. Then an another concept, representative elementary area (REA) is proposed (Wood et al., 1988). The REA concept assumes that variability is integrated over a large enough area, so that the effects at the point scale are attenuated (Grayson and Moore, 1992). The hydrologic response can be considered as homogeneous on the REA.

In the second case, the catchment is divided into subcatchments (Rodriguez-Iturbe and Gupta, 1983). 
These units are obtained through the analysis of the topographical catchment characteristics, using a digital elevation model (DEM). This method imposes a critical area which allows to distinguish between rill flow and channel flow (Montgomery and Foufoula-Georgiou, 1993). This area represents the minimal extension of source subcatchments.

These two approaches are used to capture the main spatial variability of catchment characteristics. In the first case, homogeneous units (HRU, REA) are obtained in regards to physical characteristics and/or hydrological processes. In the second case, unit segmentation is performed by topographical analysis to obtain subcatchments (Moore et al., 1993). The question of taking into account the spatial variability of catchment characteristics still remains.

Then, aggregation scheme must be defined to integrate subcatchment variability. Area subdivision and aggregation scheme choices are closely linked.

The aggregation of catchment characteristics has repercussions on hydrologic modelling and in particular on effective rainfall modelling (Colosimo and Mendicino, 1996; Thieken et al., 1999). The hydrologic processes can be analysed on a local, subcatchment or catchment scale. Aggregation scheme necessitates the linking together of scales, by a process called "scaling"' (Klemes, 1983). Scaling difficulties in hydrology have been identified (Bloschl and Sivapalan, 1995), but no "factor scale" method has been found to link scales (Ambroise, 1999). Various methods have been developed to analyse the aggregation effects. Among them, descriptive statistical analysis on subcatchment-by-subcatchment basis has been used. The entropy theory (Shannon and Weaver, 1962) can also be used to study aggregation effects (Singh, 1999). In this paper the effects of land use aggregation on effective rainfall modelling are studied, on a subcatchment-by-subcatchment basis, using statistical analysis and the entropy theory. We chose the SCS method to assess effective rainfall according to land use aggregation scheme and threshold-areas.

The SCS method is well adapted to catchment scale studies (Mishra et al., 1999; Beven, 2001) and implemented in many hydrological models (Williams et al., 1982; Leonard et al., 1987). It uses a curve number value which is based on infiltration characteristics, land use and cover, agricultural management and conservative practices (Soil-conservation-service, 1972).

Land use aggregation effects on effective rainfall calculation is assessed on Pallas catchment, $50 \mathrm{~km}^{2}$, located in the south of France.

\section{Materials and methods}

Geographic information system (GIS) is used in aggregation effects studies. Firstly, before the modelling step, GIS is a useful tool to integrate catchment spatial characteristics like soil, land use and topography (Fortin et al., 1990). Spatial characteristics of rain (Chaubet et al., 1999) and initial moisture conditions (Engman, 1997) can be integrated by GIS. Secondly, the aggregation step requires the use of a spatial tool to obtain area segmentation (Jeton and Larue-smith, 1993). At the end, effects of aggregation scheme on characteristics variability can be performed using GIS (Colosimo and Mendicino, 1996; Becker and Braun, 1999; Thieken et al., 1999; Dautrebande and Laime, 2000).

The database management system set up to study catchment hydrological response uses the GIS ARC/ INFO software (Environment Systems Research Institute, Redlands, California), on a SUN SPARC station platform (SUN Microsystems, Mountain View, California) using a UNIX operating system.

The sub-areas segmentation method, land use aggregation scheme and effective rainfall calculation must be integrated to study land use aggregation effects on hydrological response.

\subsection{Subcatchment segmentation}

The first step is to divide the catchment area into subareas through an analysis focused on hydrological functioning. This step involves extracting subcatchments using topographical information obtained with the DEM. In order to derive channel network from the DEM, it is assumed that there is flow into a channel if its upstream area exceeds a critical area. In this case, the cell is considered as a channel segment. At the channel junctions and river sources, the "contributing subareas" are calculated using the watershed function of ARC/INFO.

The subcatchment delineation is performed with different threshold-areas from the more detailed unit area ("local scale") to the total catchment area.

\subsection{Land use aggregation}

The second step consists in implementing land use aggregation schemes. Land use catchment characteristics are aggregated from local scale to subcatchment scale. For the aggregation scheme, we chose the main land use (the land use covering the largest area) to characterise the subcatchment that we have called the main land use aggregation scheme. This aggregation scheme is adopted on a subcatchment-by-subcatchment basis. This simple aggregation scheme allows the gradual reduction of land use spatial variability by increasing of the threshold-area.

The evolution of intra-subcatchment land use variability is studied using two methods.

The first method is a statistical approach. We have defined the main land use index (MLI) and its standard 
deviation among all the subcatchments (std dev), that are calculated by

MLI $1 / 4 \frac{1}{k}{ }_{i^{1} / 41}^{\mathbf{X}} \operatorname{Pmax}_{\mathrm{i}}$

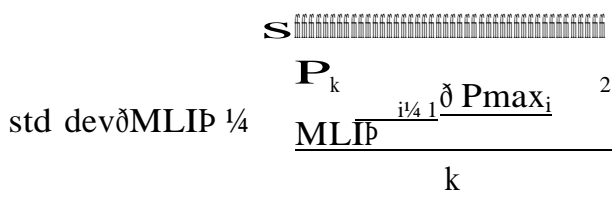

where $\operatorname{Pmax}_{\mathrm{i}}$ is the area of main use of the $\mathrm{i}$ subcatchment divided by the $\mathrm{i}$ subcatchment area, and $\mathrm{k}$ the number of subcatchments.

The second method uses the entropy index (Singh, 1999). The entropy can be characterised by the entropy index $\mathrm{H}^{0}$ defined by

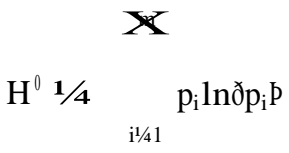

where $p_{i}$ is area of land use $i$ divided by the total catchment area and $\mathrm{m}$ is the number of land use types. The higher the entropy index $\mathrm{H}^{0}$ is, more important the catchment land use variability.

\subsection{Effective rainfall calculation}

The land use aggregation scheme has repercussions on hydrologic modelling which is here assimilated to effective rainfall. The SCS-CN method is used to calculate effective rainfall in function of land use, soil type and antecedent moisture. This method requires the calibration of one parameter (SCS parameter) to adjust the initial abstraction, due to surface storage, interception and infiltration, prior to runoff (Appendix A).

This approach can be adopted in optimal conditions by using GIS-based overlay methods, where a map of SCS soil type is superimposed onto a land use classification to produce a map of $\mathrm{CN}$ for a catchment (Mattikalli et al., 1996; Karvonen et al., 1999; Dautrebande and Laime, 2000).

To analyse the effects of land use aggregation scheme on catchment hydrological response, a homogeneous soil is considered here for all testing steps. Therefore, for different threshold-areas, the effective rainfall evolution depends only on land use aggregation. Our purpose is to determine the existence of a critical threshold-area or subcatchment size appropriate for the application of hydrological modelling.

For each studied event, a SCS model is calibrated with rain and runoff data. Calibration is performed to determine the SCS parameter. This calibration is set with the more detailed land use cover available without aggregation. Then, SCS model is applied given the calibrated parameter value for all aggregation steps. Therefore, sensibility of land use aggregation scheme on

\section{Application and results}

\subsection{The Pallas catchment}

The land use aggregation effects on hydrological response is studied on the Pallas river, located in the south of France (Fig. 1). Its catchment area $\left(52 \mathrm{~km}^{2}\right)$ is characterised by a sparse population.

The database created for this study includes the DEM

with a $50 \mathrm{~m}$ horizontal resolution and the land use coverage classified from a 1996 SPOT image with a $20 \mathrm{~m}$ resolution.

Two land use classification types are proposed (Fig. 2 ). The first land use classification is characterised by 10 categories: two artificial themes (residential area and urban area), five farming themes (bare soil, vineyard,

orchard, truck farming and crops) and three natural themes (moor, garrigue and wood). The second is ob-

SCS model results is studied (effective rainfall calculated/observed). 
tained by simplifying the previous classification types into three categories: artificial, farming and natural.

\subsection{Subcatchment segmentation and land use aggregation}

Subcatchment segmentation is carried out using 13 threshold-areas from 12500 to $52 \mathrm{~km}^{2}$ (equivalent to the overall catchment area). For each segmentation, land use maps are worked out on a subcatchment-by-subcatchment basis. Each subcatchment is associated to its main landuse, i.e. the land use covering the largest area of the given subcatchment. For each subcatchment segmentation, we obtain two aggregated land use maps, one for each land use classification (Figs. 3 and 4).

The classification used to qualify land use has serious repercussions on the aggregated map. On a given subcatchment, the aggregation scheme leads to contradictory results in terms of land use themes for the two classification types (see definite subcatchments in Figs. 3 and 4).

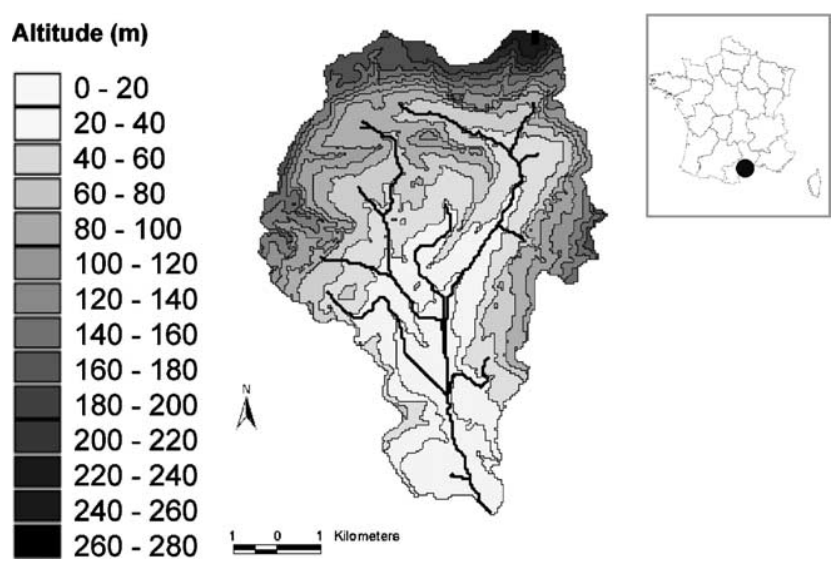

Fig. 1. Pallas catchment location (Herault, France). 


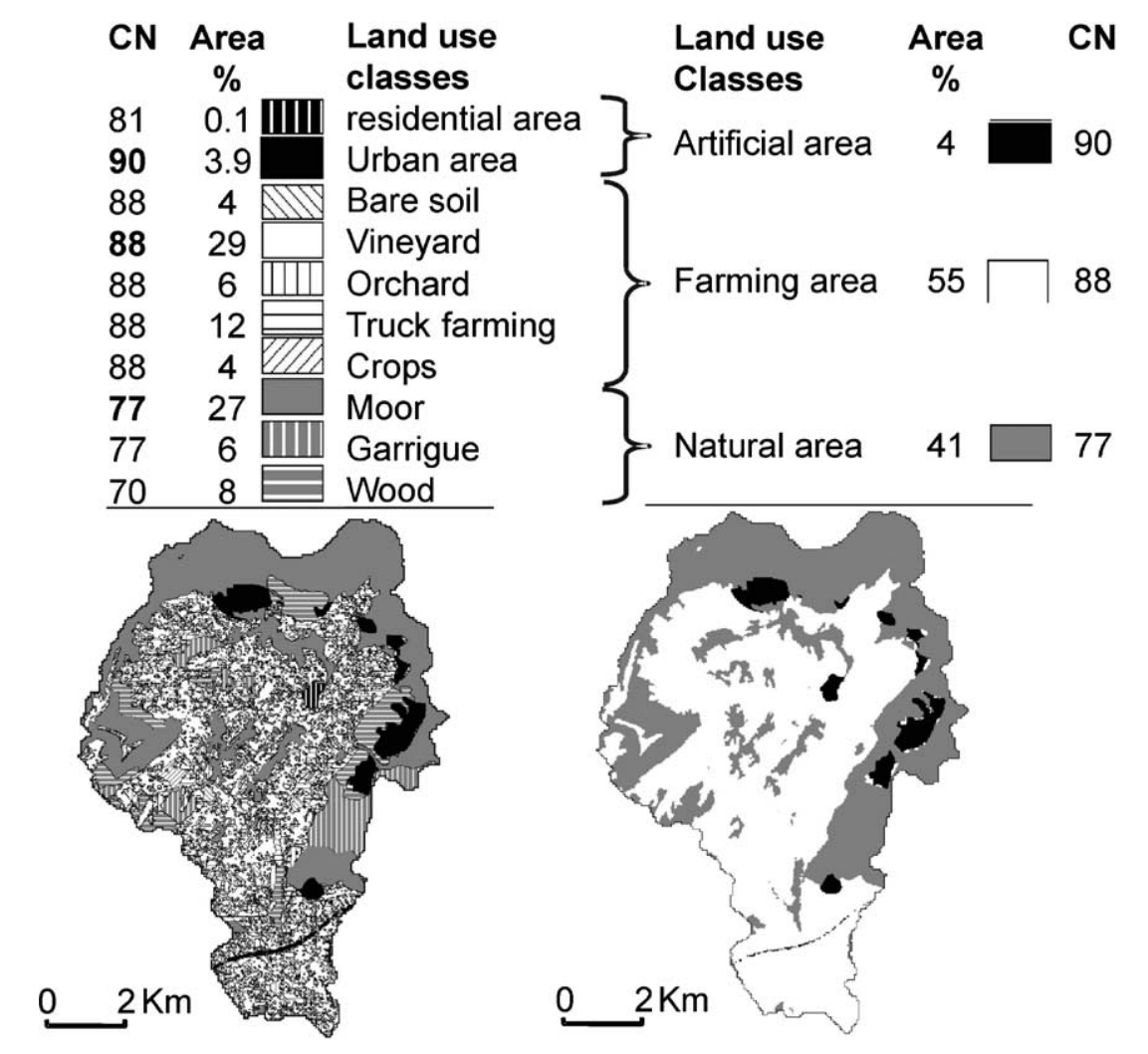

Fig. 2. Land use description and curve number associated for the two classification types.

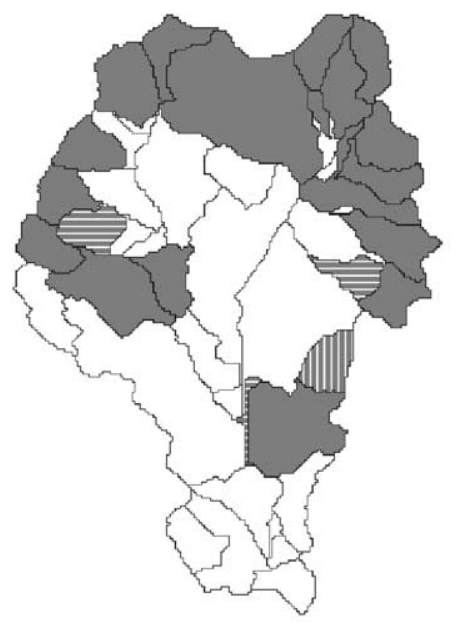

Threshold-area $=0.8 \mathrm{~km}^{2}$

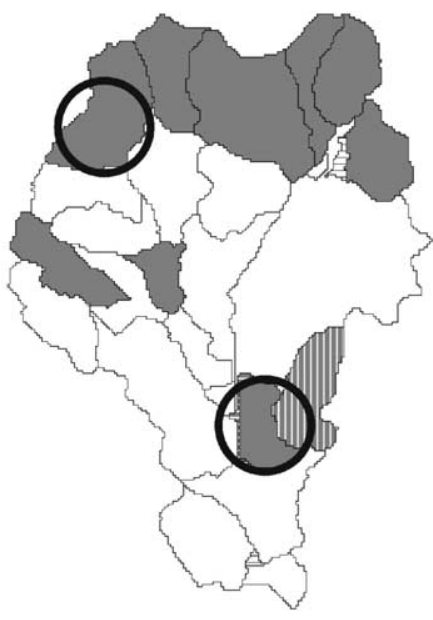

Threshold-area $=1.6 \mathrm{~km}^{2}$

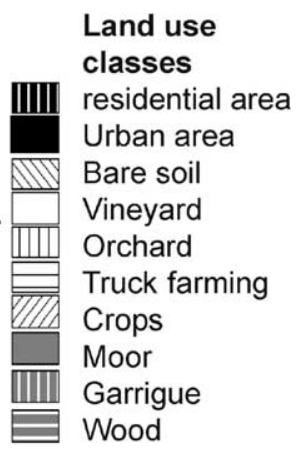

Land use

residential area

Urban area

Bare soil

Vineyard

Crops

Wood

Fig. 3. Land use aggregation map for different segmentations with the 10 class classification.

As described in Section 2.2, the intra-subcatchment variability of land use for each segmentation is studied, using two methods. Firstly, the main land use index and its standard deviation among all the subcatchments are plotted versus the subcatchment segmentation, represented by the ratio threshold-area/catchment area (Fig. 5). Then, we have plotted the entropy index versus subcatchment segmentation ratio (Fig. 6).

The main land use index decreases from 1 for the more detailed land use cover to 0.58 (respectively 0.3 ) for 3 class classifications (respectively for 10 class classifications). The higher the threshold-area is, the lower the intra-subcatchment homogeneity for land use. From a $6.4 \mathrm{~km}^{2}$ threshold-area (that is to say $12 \%$ of the catchment area), we can observe a break with the main land use index increasing (Break 1). This point will be discussed later.

The entropy index, and therefore the land use variability, is higher for the 10 category classification than for the 3 category classification. After the $0.8 \mathrm{~km}^{2}$ 

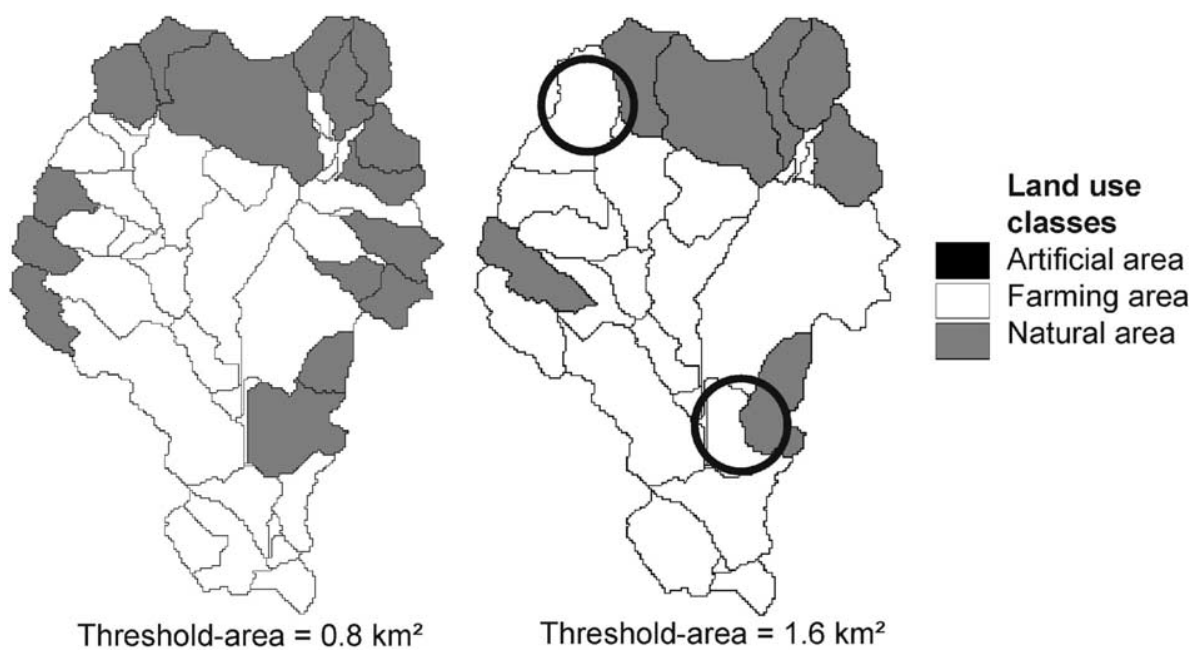

Fig. 4. Land use aggregation map for different segmentations with the 3 class classification.
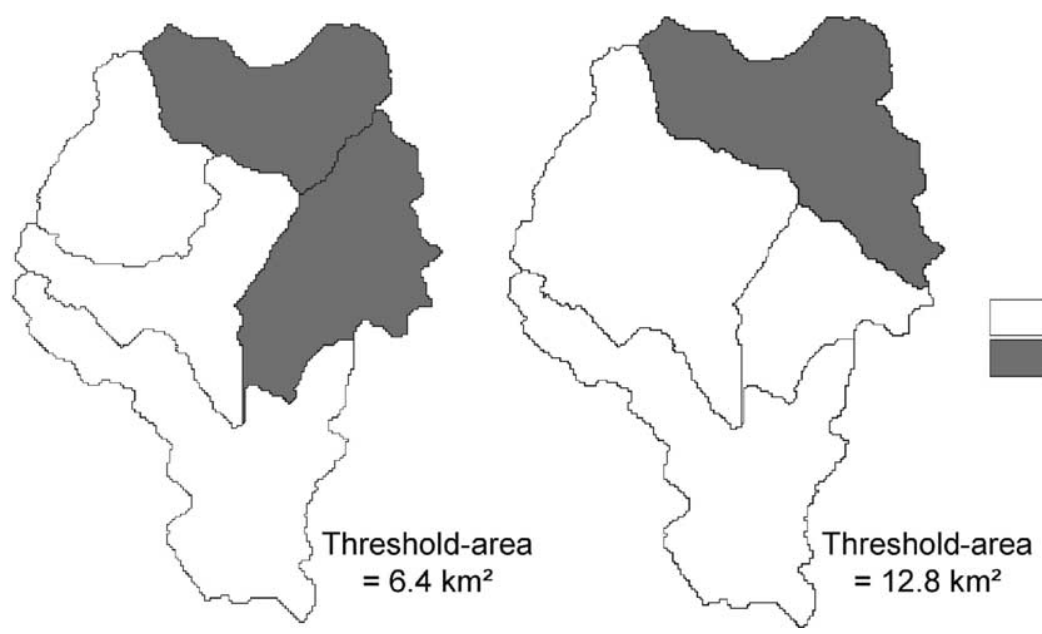

Land use classes

Fig. 5. Evolution of subcatchment land use homogeneity with aggregation.

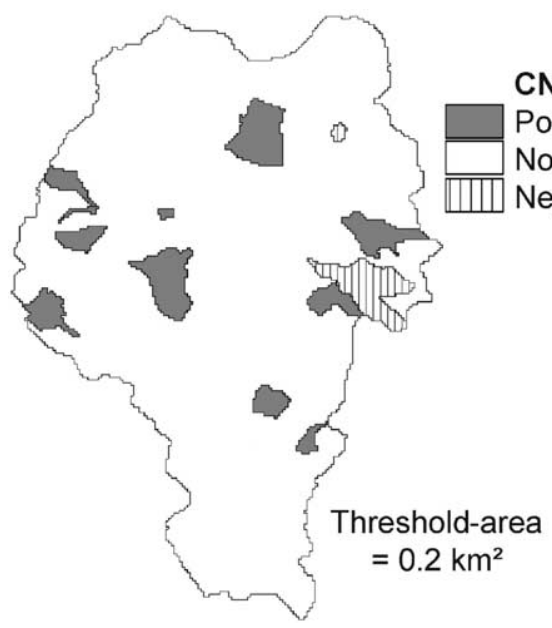

\section{CN difference}

Positive variation No variation

Negative variation

Fig. 6. Evolution of land use entropy index with aggregation. 


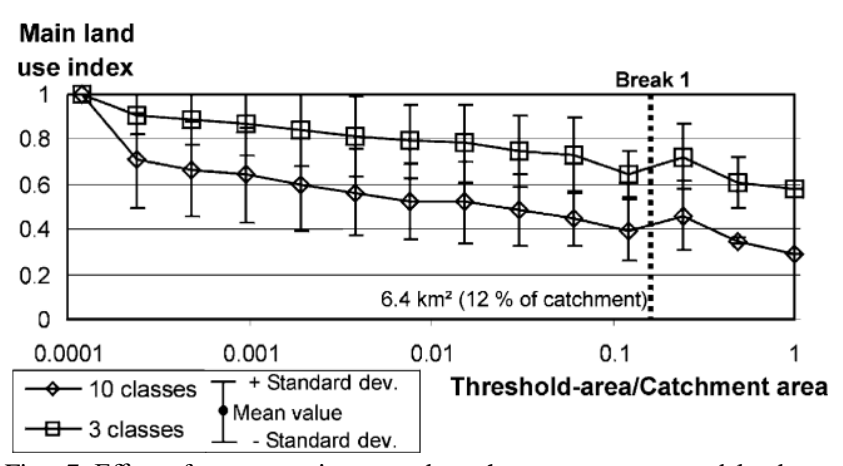

Fig. 7. Effect of segmentation on subcatchment geometry and land use characteristics (10 class classification).

threshold-area, we can observe a change in the index curve slope (Break 2). After the $6.4 \mathrm{~km}^{2}$ threshold-area (Break 1), the entropy index is different with the two classification types.

Two breaks in land use aggregation steps have been pointed out. The great modification of subcatchment geometry between 6.4 and $12.8 \mathrm{~km}^{2}$ can explain the Break 1 (Fig. 7). The interpretation of the Break 2 is more difficult. It could be caused by the decrease of the number of subcatchments under a critical value (between 56 and 32 subcatchments) which has to be confirmed on other catchment (Fig. 6). These 2 breaks are function of the geometry and the land use of the Pallas catchment and their existence should be analysed on other catchments.

\subsection{Effects of classificationtype on curve number $(\mathrm{CN})$} calculation

The SCS method requires the soil series knowledge. In this theoretical approach of effective rainfall sensibility a homogeneous soil type (group $\mathrm{C}$ with slow permeability in SCS model) is used here for the catchment. According to SCS method, a runoff curve number $(\mathrm{CN})$ is calculated for each hydrologic soil-cover complexes.

For each threshold-area, the curve number is calculated on a subcatchment-by-subcatchment basis. The higher the threshold-area is, the more the $\mathrm{CN}$ difference varies between the two classification types. To illustrate this effect, the difference between the $\mathrm{CN}$ calculated with the 3 and 10 class classifications is calculated (Fig. 8).

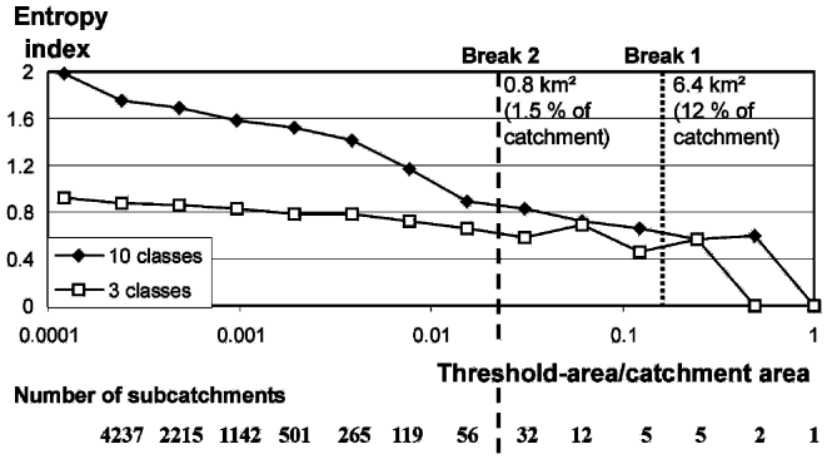

Fig. 8. $\mathrm{CN}$ value difference between the 3 and 10 class classification.

The calculation of the mean $\mathrm{CN}$ shows that up to the $0.8 \mathrm{~km}^{2}$ threshold-area (or $1.5 \%$ of the catchment), this difference is not significant (Fig. 8). After this thresholdarea, this difference is significant.

\subsection{Effects of aggregationon effective rainfall calculation}

Three events were used to study the land use aggregation effects on effective rainfall calculation. The following table summarises their characteristics. The rainfall is measured on one point on the catchment. The 3 events have been chosen in such a way than the discharge at the outlet is only due to surface runoff: the effective rainfall is then equal the flow. The uncertainty on the measurements of the discharge data leads to estimate a $10 \%$ uncertainty on the effective rainfall. Table 1 .

For each event, the SCS parameter is calibrated with rainfall and runoff data and its value is 0.5 . This calibrated value is higher than 0.2 , which is usually set in the SCS method. So, in this theoretical study, the Pallas catchment is more permeable than that given with the SCS empirical estimation.

The effects of aggregation on effective rainfall are illustrated for the 3 events (Fig. 9) and for the two classifications with the event 1 (Fig. 10).

Until the $0.8 \mathrm{~km}^{2}$ threshold-area $(1.5 \%$ of the catchment) there is no difference between the 3 events for a given classification taking into account the $10 \%$ of data uncertainty (Fig. 9). Moreover, until the $0.8 \mathrm{~km}^{2}$ threshold, the 2 land-use classifications give the same results on the event 1 (Fig. 10). Beyond $6.4 \mathrm{~km}^{2}$

Table 1

Event characteristics on Pallas catchment

\begin{tabular}{llll}
\hline & Event 1 & Event 2 & Event 3 \\
\hline Rainfall $(\mathrm{mm})$ & 143 & 65 & 54 \\
Effective rainfall (mm) & 28.6 & 15.6 & 9.72 \\
Runoff coefficient (\%) & 20 & 24 & 18 \\
Total rainfall 10-day (mm) & 0 & 47 & 57 \\
Antecedent moisture (SCS method) & Dry & Average & Average \\
\hline
\end{tabular}




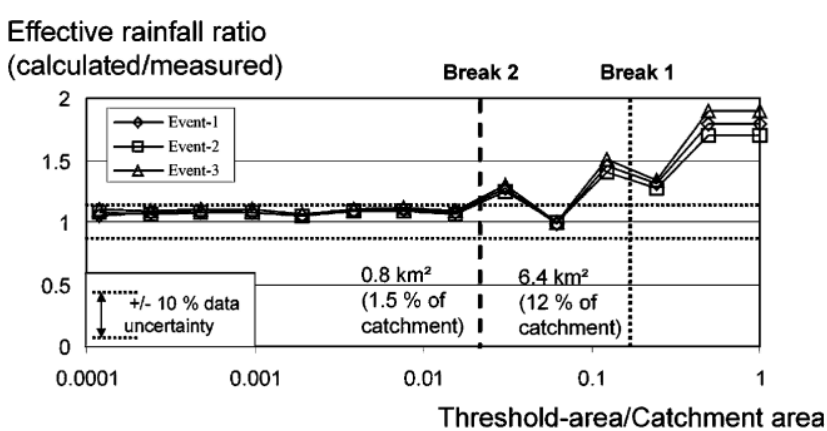

Fig. 9. Evolution of calculated/measured effective rainfall with aggregation (3 events with 3 classes classification).

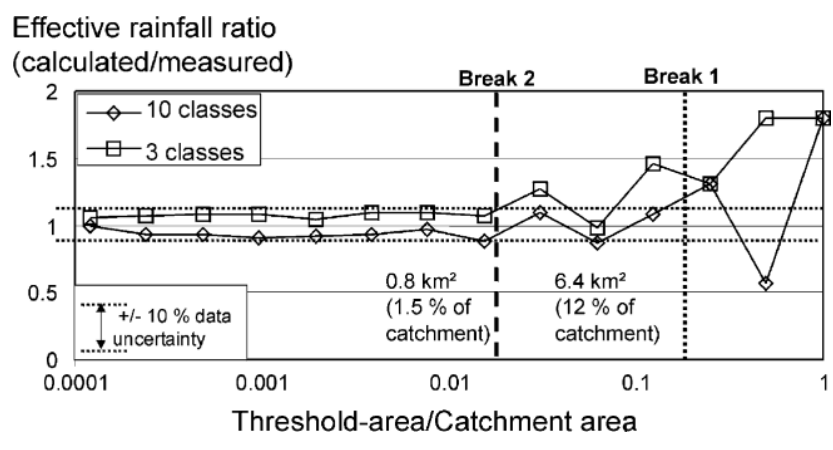

Fig. 10. Evolution of calculated/measured effective rainfall with aggregation (event 1 with the two classifications).

threshold-area ( $12 \%$ of the catchment), we observe an important difference between the 2 land-use classifica-

tions (Fig. 10). The difference between events remains small (Fig. 9), but the errors on the estimation of the

effective rainfall increase strongly. Moreover, beyond the $6.4 \mathrm{~km}^{2}$ threshold, we notice the beginning of a dysfunction: the effective rainfall calculation evolves erratically with aggregation.

The comparison of the two classification types demonstrates that higher the class number is, the higher the upper borderline of the aggregation effect (Fig. 10).

\section{Conclusions}

This paper shows that land use aggregation and land use classification type have effects on hydrologic modelling and in particular on effective rainfall modelling.

The statistic approach, with the determination of the main land use index allows the identification of borderline threshold-areas from which the evolution of land use variability is erratic. The entropy index, on the other hand, shows that land use variability rapidly decreases. So, to correctly describe the catchment land use, the best way is to deal with the more detailed cover (Vieux, 1993). But up to a critical threshold-area, the land use aggregation effect on effective rainfall calculation is not significant. So in the scope of hydrological modelling, a more detailed land use description is not required.
A similar study can be conducted to test the effect of soil aggregation since the SCS method refers also to soil types.

In this paper, it was demonstrated that for a hydrological purpose, up to a critical threshold-area the aggregation does not affect effective rainfall modelling. This critical-area is obtained near $1 \mathrm{~km}^{2}$ (2\% of the catchment) for the 3 class classification. This thresholdarea is usually given in scaling purpose (Farajalla and Vieux, 1995). Further study is needed to assess if this threshold-area is constant for different catchments or if there is an aggregation scheme bias. It will be interesting to determinate if the threshold-area concerns the subcatchment area $\left(1 \mathrm{~km}^{2}\right)$ or the catchment percentage (2\%). After this critical threshold-area, another aggregation method such as the mean curve number calculation must be adopted to characterise the catchment.

\section{Appendix A. The SCS method}

The SCS method is based on runoff equation developed in 1947 (Mockus, 1949). A relationship between accumulated rainfall and accumulated runoff was derived from experimental plots for numerous soils and vegetative cover conditions (Soil-conservation-service, 1972).

This equation is:

PE $1 / 4$ ðP

\begin{tabular}{cc}
$\frac{\mathrm{P}}{\mathrm{IaP}} \underline{2}$ \\
\hline${ }^{1 / 4}$ & Ia $\mathbf{p} \mathrm{SP}$
\end{tabular}

ð1 $1 \mathrm{P}$

where PE is accumulated effective rainfall, $\mathrm{P}_{\mathrm{i}} \mathrm{s}$ accumulated rainfall, Ia is initial abstraction (including surface storage, interception and infiltration prior to runoff) and $\mathrm{S}$ is potential maximum retention.

An empirical relationship used in the SCS runoff equation relating Ia and $S$ :

Ia $1 / 4$ a $\quad S$

ð2P

The calibration of this coefficient a can be performed with runoff data. In most case, the value 0.2 can be set. After an analysis of a large number of runoff events for various catchments, a family of curves has been formulated (Soil-conservation-service, 1972).

$\mathrm{S}$ values are transformed into curve numbers $(\mathrm{CN})$ by the following equation:

CN 1/4 1000=ð10 p SP

The specific curve number to employ is determined by evaluation of land use (vegetation and land treatment or farming practices), soil series and the soil moisture.

\section{References}

Abbott, M.B., Bathurst, J.C., Cunge, J.A., O Connell, P.E., Rasmussen, P.E., 1986. An introduction to the European hydrological 
system. Systeme Hydrologique Europeen, "SHE", 1: History and phylosophy of a physically-based, distributed modelling system. Journal of Hydrology 87, 45-59.

Ambroise, B., 1999. Gen ese des debits dans les petits bassins versants ruraux en milieu tempere: 2-Modelisation systemique et dynamique. Revue des Sciences de 1Eau 12/1, 123-153.

Becker, A., Braun, P., 1999. Disaggregation, aggregation and spatial scaling in hydrological modelling. Journal of Hydrology 217, 239252.

Beven, K., 1989. Changing ideas in hydrology. Journal of Hydrology $105(1 / 2)$.

Beven, K.J., 2001. Rainfall-Runoff Modelling-The Primer. Wiley, Chichester, pp. 356.

Beven, K.J., Kirkby, M.J., 1979. A physically-based variable contribution area model of catchment hydrology. Hydrology Science Bulletin 24 (1), 43-69.

Bloschl, G., Sivapalan, M., 1995. Scales issues in hydrological modelling: a review. Hydrological Processes 9, 251-290.

Chaubet, I., Haan, C.T., Grunwald, S., Salisbury, J.M., 1999. Uncertainty in the model parameters due to spatial variety of rainfall. Journal of Hydrology 220, 48-61.

Chow, V.T., Maidment, D.R., Mays, L.W., 1988. Applied Hydrology. McGraw-Hill International Editions, New York, p. 572.

Colosimo, C., Mendicino, G., 1996. Scale definition in an integrated GIS hydrological model: a case study, HydroGIS 96: application of geographic information systems in hydrology and water resources management, Vienne, Autriche, avril 1996. no. 235. IAHS Publication, 385-393.

Dautrebande, S., Laime, S., 2000. Model and spatial database to assess design peak flow rates in the Walloon region (Belgium). In: Floodware final report. Programme climate and environment 1994-1998. Area 2.3.1: hydrological and hydrogeological risks, Contract: ENV4-CT96-0293, Cemagref Editions, Antony, 83-94.

Eagleson, P.E., 1972. Dynamics of flood frequency. Water Resource Research 8 (4), 878-899.

Engman, E.T., 1997. Soil moisture, the hydrologic interface between surface and ground waters, In: Remote sensing and geographic information systems for design and operation of water resources systems, Proceedings of Rabat Symposium S3, 242. IAHS, 129140.

Farajalla, N.S., Vieux, B.E., 1995. Capturing the essential spatial variability distributed hydrological modelling: infiltration parameters. Hydrological Processes 9, 55-68.

Fortin, J.P., Moussa, R., Bocquillon, C., Villeneuve, J.P., 1990. Hydrotel, a distributed hydrological model compatible with remote sensing and geographical information systems. Revue des Sciences de 1 Eau 8 (1), 97-124.

Grayson, R.B., Moore, L.D., 1992. Physically based hydrologic modelling 2. Is the concept realistic? Water Resource Research 26 (10), 2659-2666.

Jeton, A.E., Larue-smith, J., 1993. Development of watershed models for two Sierra Nevada basins using a geographic information system. Water Resources Bulletin 29 (6), 923-932.
Karvonen, T., Koivusalo, H., Jauhiainen, M., Palko, J., Weppling, K., 1999. A hydrological model for prediction runoff from different land use areas. Journal of Hydrology 217, 253-265.

Kite, G.W., Kouwen, N., 1992. Water modeling using land classifications. Water Resource Research 28 (12), 3193-3200.

Klemes, V., 1983. Conceptualization and scale in hydrology. Journal of Hydrology 65 (1-3), 139-158.

Leonard, R.A., Knisel, W.G., Still, D.A., 1987. GLEAMS: groundwater loading effects of agricultural management systems. Transactions of the ASAE 30 (5), 1403-1418.

Maidment, D.R., 1993. GIS and hydrologic modeling. Environmental Modeling with GIS, 147-167.

Mattikalli, N.M., Devereux, B.J., Richards, K., 1996. Prediction of river discharge and surface water quality using an integrated geographical information system approach. International Journal of Remote Sensing 17 (4), 683-701.

Mishra, S.K., Kumar, S.R., Singh, V.P., 1999. Calibration and validation of a general infiltration model. Hydrological Processes $13,1691-1718$.

Mockus, V., 1949. Estimation of total (and peak rates of) surface runoff for individual storms, Exhibit A in Appendix B, Interim Survey Report, Grand (Neosho) River watershed, USDA, Washington, DC.

Montgomery, D.R., Foufoula-Georgiou, E., 1993. Channel network source representation using digital elevation models. Water Resources Research 29 (12), 3925-3934.

Moore, I.D., Turner, A.K., Wilson, J.P., Jenson, S.K., Band, L.E., 1993. GIS and land- surface-subsurface process modelling. Environmental Modelling with GIS, 197-230.

Rodriguez-Iturbe, I., Gupta, V.K., 1983. Scale problems in hydrology. Journal of Hydrology 65 (special issue), 175-208.

Ross, B.B., Contractor, D., Shanholtz, V.O., 1979. A finite element model of overland and channel flow for assessing the hydrologic impact of landuse change. Journal of Hydrology 41, 1-30.

Shannon, C.E., Weaver, W., 1962. The mathematical theory of communication. University of Illinois Press, Urbana, USA.

Singh, V.P., 1999. The entropy theory as a tool for modelling and decision-making in environmental and water resources. Water SA 26 (1), 1-11.

Soil-conservation-service, 1972. National Engineering Handbook, section 4, Hydrology, USDA, Washington DC.

Thieken, A.H., Lucke, A., Diekkruger, B., Richter, O., 1999. Scaling input data by GIS for hydrological modelling. Hydrological Processes 13, 611-630.

Vieux, B.E., 1993. Nonpoint-pollution model sensitivity to grid-cell size. Journal of Water Resources Planning and Management 119 (2), 141-157.

Williams, J.R., Dyke, P.T., Jones, C.A., 1982. EPIC: a model for assessing the effects of erosion on soil productivity. Ecological Modeling, Colorado State University, 24-28 May.

Wood, E.F., Sivapalan, M., Beven, K.J., 1988. Effects of spatial variability and scale with implications to hydrologic modeling. Journal of Hydrology 102 (1/4), 29-47. 